\title{
Impact of Energy Consumption, Economic Growth, and FDI through Environmental Kuznets Curve: Perspective from Belt and Road Initiative and Pakistan
}

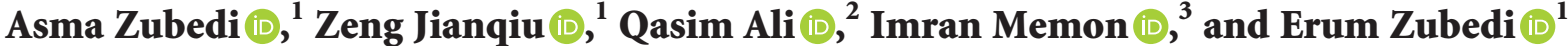 \\ ${ }^{1}$ Beijing University of Posts and Telecommunication Beijing (BUPT), Beijing, China \\ ${ }^{2}$ Mehran University of Engineering and Technology, Jamshoro, Pakistan \\ ${ }^{3}$ Department of Computer Science, Bahria University, Karachi, Pakistan
}

Correspondence should be addressed to Asma Zubedi; asmazubedi.az@hotmail.com

Received 13 June 2021; Accepted 31 December 2021; Published 12 February 2022

Academic Editor: Gianpaolo Di Bona

Copyright (C) 2022 Asma Zubedi et al. This is an open access article distributed under the Creative Commons Attribution License, which permits unrestricted use, distribution, and reproduction in any medium, provided the original work is properly cited.

A significant corridor under the "Belt and Road Initiative" is announced by the government of China for numerous transport and energy projects. China focuses greatly on the sustainability of these projects, in accordance with Green Investment Principles. For this, environmental, social, governance, and technological considerations are taken into account. This paper offers a novel assessment of the impact of green sustainability under BRI and the current emission scenario in Pakistan. The question that needs to be addressed here is whether the projects under Belt and Road Initiative are as environment friendly as they claim. In the first phase of this study, we review theories establishing evidence based on existing literature to determine the influence of Belt and Road on economic development. In the next phase, we use Environment Kuznets Curve and apply estimates from Johansson's Cointegration Test to quantify the present environmental scenario of Pakistan and probable environmental risk portrayed by the China-Pakistan Economic Corridor (CPEC). This paper helps in determining the relationship between carbon emission and three major variables including energy consumption, economic growth, and foreign direct investment (FDI). Cointegration analysis is applied on time series data comprising of a 40 years' period from 1979 to 2019 . The paper finds that (i) the belt and road corridors could substantially improve trade, foreign investment, and living conditions for citizens in participating countries; (ii) moreover, this study confirms the presence of one cointegrated equation suggesting the presence of a long term relationship between the $\mathrm{CO}_{2}$ and independent variables and a short run association running from EnC to $\mathrm{CO}_{2}$. The study also proposes a Green BRI Model which formulates a body that devises environmental performance standards, reviews procedures, and ensures that they get implemented on all CPEC projects. The Belt and Road Initiative increases emissions among participating countries. China and corridor economies need to adopt strict policy reforms that increase transparency, expand trade, improve debt sustainability, and mitigate environmental, social, and corruption risks.

\section{Introduction}

The most renowned One Belt, One Road Policy (OBOR), initiated by People's Republic of China, is a bidirectional strategy. This project is devised in such a way that it plans to enter the West by building a route through noncoastal countries (New Silk Road) and through deep waters [1]. The People's Republic of China bears the vision of incorporating Chinese dream and the global dream by the international strategy of connectivity [2]. The strategic initiative by China to construct "21st Century Maritime Silk Road" and the "Silk Road Economic Belt" (SREB) aims to bring wealth and development in the region.

There exists a need to understand environmental risks associated with Chinese initiated megaproject under BRI and specifically under CPEC. An insight for the New Silk Road will assist in analyzing the impact of CPEC on Pakistan and its neighboring countries [3]. Major contributors of GHG emissions are infrastructure, energy ventures, and transportation sector. It is responsible for approximately 
fourteen percent of total anthropogenic emissions around the globe. Efforts are made to develop a low-carbon economy by determining the factors contributing to the Green House Gases (GHG). The hazardous effect of environmental degradation in Pakistan is evident in recent decades.

Pakistan stands 16th on IOV (Index of Vulnerability) checked against statistics of 170 nations [4]. It stands 135th for release of GHG on international standards. According to 2012 Global Climate Risk Index of German watch, Pakistan occupies 8th position when checked against 180 countries internationally [5]. Although much discussion on the Belt and Road Initiative is conducted, significant efforts on its effects in the perspective of Pakistan have not been carried so far.

Global warming has become a hazard for sustainable economic development [6]. Economic development depends on infrastructure and energy sector of a country. Energy is the defining variable for any course of production activity. It is vital for socioeconomic development of a country. Rapid growth in industrial network has led to sudden escalation in demand for energy. A tremendous growth in fossil energy consumption has a substantial impression on increasing carbon emission [7]. Therefore, it is necessary to understand that a reasonable control and distribution of fuel consumption is indispensable to reduce $\mathrm{CO}_{2}$ emission [8]. Constant development of industry involves fossil fuel combustion that ultimately enhances $\mathrm{CO}_{2}$ emission. According to statistics, energy- $\mathrm{CO}_{2}$ emission accounts for $80 \%$ of all greenhouse gases [9] around the world.

According to a research [10], the impact of economic activities can be classified into three basic factors, i.e., scale, composition, and the technical progress effect. Scale effect is involved when the impact of economic growth influences the level of pollution. When economic structure develops from modification of agricultural-based to manufacturing and services-based offerings, we regard this as the composition effect. In the scenario where advanced technology is implied that results in decrease of pollutants, it is referred to as the technological effect. Kuznets presented this in the form of an inverted U-shape relationship which is presently known as Environment Kuznets Curve [11].

Initial study based on EKC hypothesis [12] has analyzed economic growth and environment nexus. The research is extended by several researchers [13-16]. The earliest study is based on an inverted U-shaped curve proposed by Kuznet [11] that explains the association for inequality and per capita income. It became the foundation for Grossman and Krueger [17] who proposed a quadratic relationship between per capita income and pollution. The important terms and their abbreviations used in this research are mentioned in Table 1.

\section{Belt and Road Initiative}

Existing literature on BRI indicates that many countries will be directly affected by the infrastructure improvements including Pakistan. Pakistan has one of the impoverished economies that expects to gain great welfare from this project. According to a recent study, by the year 2030 Pakistan will gain a benefit of $8.6 \%$ share of the total profit
TABLE 1: Abbreviations and their terms.

\begin{tabular}{lc}
\hline Terms & Abbreviations \\
\hline Akaike information criteria & AIC \\
Augmented Dickey-Fuller & ADF \\
Autoregressive deterministic test & ARDL \\
Belt road initiative & BRI \\
China national petroleum corporation & CNPC \\
China-Pakistan Economic Corridor & CPEC \\
Environment Kuznet curve & EKC \\
Foreign direct investment & FDI \\
Gross domestic product & GDP \\
Green house gas & GHG \\
International energy agency & IEA \\
Index of vulnerability & IOV \\
Oil and gas climate initiative & OGCI \\
One belt one road & OBOR \\
Pollution haven hypothesis & PHH \\
Silk road economic belt & SREB \\
Vector autoregressive model & VAR \\
Vector error correction model & VECM \\
\hline
\end{tabular}

from the BRI. It is projected to be achieved by enhancing trade, reduction in actual costs, infrastructure development, investment in energy projects, development of Gawadar port, improvement in highway, rail and pipeline infrastructure, and other such projects planned under CPEC. The plan includes development of Peshawar-Karachi Motorway. It also focuses on reducing costs of petroleum and coal products. Trade tends to increase due to reduction of trade and imports costs and foster import of agricultural goods and textiles.

The economic belt under China's Belt and Road Initiative (BRI) has been a promising endeavor across Asia, Europe, and Africa. The economic development under BRI encompasses the cumulative Gross Domestic Product (GDP) of around USD 21 trillion [18]. There are more than 72 countries under BRI that cover six major corridors. These corridors will develop to form a network of transportation, pipelines, waterways, and information highways and will connect industries and energy sources [19].

The Silk Road Economic Belt (SREB) shall be extended by laying down a systematic route of communication and infrastructure. As a result, Central Asia, East Asia, and South Asia are connected in an efficient manner with the Eurasian lands. The general perspective is that the countries included in project of 21st Century Maritime Silk Road program will enjoy socioeconomic benefits and substantial growth [20].

Six economic corridors under BRI [21] have been proposed as below:

(1) The China-Mongolia-Russia Economic Corridor

(2) The New Eurasian Land Bridge

(3) The China-Central Asia-West Asia Economic Corridor

(4) The China-Indochina Peninsula Economic Corridor

(5) The China-Pakistan Economic Corridor

(6) The Bangladesh-China-India-Myanmar Economic Corridor 
2.1. Environmental Impact of Belt and Road Initiative. Environmental performance of BRI may be improved by introducing a binding set of environmental framework. This could be achieved by commencing an international coalition to ensure Green Development on Belt and Road as announced by China's Ministry of Ecology and the Environment and the United Nations Environment Program in 2017. The need for this was realized under scenario of unexpected outcome from OBOR megaproject. In that case, Belt and Road investment will cause negative impact on sustainable development. Therefore, this coalition involves several nongovernment organizations, engaging both sponsors (China) and recipient countries to ensure that the investment leads to sustainability. Communities of Practice Industry may also be employed to improve prospects for Green Belt and Road. China National Petroleum Corporation (CNPC) is one of the participating firms and members in the Oil and Gas Climate Initiative (OGCI). It is a voluntary association that checks global warming to reduce the carbon footprints of energy, industry, and transportation [22]. All companies that participate in OGCI need to meet certain criteria and must be in consensus with the goals of Paris Climate Agreement.

2.2. CPEC: A Game Changer for Pakistan. CPEC aims to open routes between China and Pakistan to connect through railroads and highways. Much debated Gwadar port will link China's northwestern city of Kashgar through $3000 \mathrm{kms}$ network of roadways. It will give free access to China for freight carriers at Gwadar by being time and cost effective. Furthermore, it is planned to construct nine economic zones on CPEC. CPEC infrastructural planning is expected to stimulate Pakistan's industrial zone. Substantial developmental work is already in progress. As a second phase plan, a six-lane motorway comprising of $1300 \mathrm{~km}$ Karakoram highway is under construction. It will pass through the prehistoric silk road running through the route of Xinjiang and enter the province of Punjab. Moreover, public transport system is also being upgraded.

CPEC agreement involves the following:

(i) Construction of the Gwadar Eastbay Expressway

(ii) Development of Gwadar New International Airport

(iii) Development of a Technical and Vocational Training Institute in Gwadar [23-27]

2.3. Energy Projects under CPEC and GHG Emissions. The economic development in recent years has witnessed acute shortage of energy. CPEC offers various energy ventures with an aim to mitigate energy shortfall once they are implemented successfully. Industrialization and an increase in pollution are a few of the causes of energy crises in Pakistan. Energy projects under CPEC will generate 17000 megawatts of energy for Pakistan's grid through coal, nuclear, and renewable energy projects. A sum of \$34 billion is invested in energy ventures whereas early harvest projects under CPEC are already in process.

Investments under CPEC umbrella are likely to provide momentous increase in GDP growth of 1.5\% during 2015 to 2020. According to Planning Commission of Pakistan, 2015, it is expected to be enhanced by $1 \%$ from 2010 to 2030 . The government of Pakistan along with China's collaboration has devised the policy framework to control prevailing energy crisis by gaining benefits from the potential CPEC opportunities. However, the focus is also on exponential increase in GHG emissions from energy and industrial development in Pakistan. An increase in GHG emission in all economic sectors is also evident from the past trend of 21 years (1994-2015) for GHG emissions which is a total of $123 \%$ increase. It is found that there exists an average $3.9 \%$ growth in GHG emissions equal to economic performance [28] that tends to be $10 \mathrm{MT}$ (metric tons) of $\mathrm{CO}_{2}$-equivalent in Pakistan. It is imperative to note here that the average GDP growth rate of Pakistan is consistent with equivalent increase in GHG emission which is around 4\% during the same year. Based on the historical trend of inventory of GHG emissions (MT $\mathrm{CO}_{2}$-equivalent) for various sectors of Pakistan, projections are made for the GDP growth rate of $4 \%$ for the year 2030 [29].

Based on above estimates, researchers extend the study by keeping the trend constant and average growth for GDP and GHG emissions for the next 15 years from 2015 to 2030. The strong correlation implies that, by the year 2030, Pakistan's total inventory of GHG emissions will amount to be $1603 \mathrm{MT} \mathrm{CO}_{2}$-equivalent. Contribution of GHG emissions from CPEC portfolio alone stands around 370.72 MT $\mathrm{CO}_{2}$-equivalent [28].

The waste generation and agriculture will contribute $5.5 \%$ and $8.1 \%$, respectively, while $1.8 \%$ GHG contribution is estimated from the land use change and forestry (LUCF) sector [30]. It implies that CPEC megaproject contributes 370.72 MT $\mathrm{CO}_{2}$-equivalent of $\mathrm{GHG}$ emissions for the year 2030 whereas total GHG emissions will be $1603 \mathrm{MT} \mathrm{CO}_{2^{-}}$ equivalent.

2.4. Environmental Threats. Analysis of existing literature indicates a number of factors that may impact the megaproject under BRI. Some of these are mentioned below:

(1) BRI involves major projects like building of highways and railroads and construction of thermal, nuclear, and hydropower plants. It also aims to develop electricity transmission systems, lying out of oil and gas pipelines, conducting mining operations, and incorporation of heavy industry. It portrays serious environmental impact like air pollution from construction work, dust, smoke emission, water scarcity, and carbon and other hazardous gaseous emissions. It causes threat to habitat and biodiversity 
due to urbanization and construction. High emission from infrastructure construction can cause global warming. It emits carbon dioxide, nitrogen, and other GHG that contaminate environment.

(2) Investment into heavy technology also portrays a threat to climate. BRI uses coal fire power plants and has spent $\$ 4.68$ billion per year in a span of five years under BRI [31]. Most part of it is invested in subcritical coal plants that release noxious, deadly air pollution.

(3) Many countries under BRI are impoverished and lack strict adherence to environmental and global protection reforms. Also, transparency on BRI projects is absent.

(4) It is observed that participating countries under BRI are more inclined towards achieving their economic development goals. They see BRI as a frontier for fostering near term new investment and employment opportunities. Thus, adherence to environmental safeguard is seen as a distraction from achieving their goals for development.

(5) The route of BRI undergoes development of six economic corridors. It passes through some remote and pristine economically important regions that may destroy natural habitat and affect rare species [32].

(6) It is also observed that BRI directly affects the development of infrastructure and construction while it indirectly affects firm responses to new routes [33].

(7) BRI passes through regions with steep terrain. Development of infrastructure may induce flooding, soil erosion, land sliding, sedimentation in rivers, and interruptions of waterways. Ecological dangers arising as a result of BRI cannot be ignored. Energy ventures leave direct effect on ozone depletion.

2.5. Objectives and Scope of This Study. This paper aims to find answers to following questions:

(i) Are the projects under Belt and Road Initiative as environment friendly as claimed?

(ii) How Belt and Road Initiative may affect climate change in Pakistan under CPEC?

To answer the research question, we undertake both qualitative and quantitative analysis. Based on our research questions, we put forward the primary objectives of this paper:

(i) To examine the impact of CPEC investment on carbon emission in Pakistan

(ii) analyze dynamic causal relationship among carbon emission, foreign direct investment, economic growth, and energy consumption

(iii) To empirically analyze short and long run existence of EKC in Pakistan
2.6. Structure of This Study. The study is organized as follows. In Section 2, we provide a brief literature review on the BRI, comparative analysis of existing literature, and this research, methodology, and model techniques. In Section 3, data analysis and result interpretation are carried out. Section 4 provides proposal for Green BRI, contribution, Gaps, and conclusion as explained in Figure 1.

\section{Literature Review}

\subsection{Theoretical Review}

3.1.1. Pollution Haven Hypothesis. There exists a tendency for polluting industries to shift from developed to developing countries as stated by pollution haven hypothesis (PHH). It seems easier to merge in developing countries due to relaxed environmental regulations $[34,35]$. The polluting productions enjoy comparative advantage in developing countries because they are more concerned about economic development as compared to sustainable development. Therefore, it is assumed accordingly that the foreign direct investment bears a negative relationship with emission of $\mathrm{CO}_{2}$ [36].

3.1.2. Halo Effect Hypothesis. Halo effect hypothesis postulates that FDI also gives a way to diffusion of sustainable production techniques. These modern and energy efficient technologies improve environmental quality of host countries (technique effect) [37]. According to researchers, FDI leads to better and cleaner environmental conditions [38].

3.1.3. Porter Hypothesis. According to this hypothesis, there is lesser emission when the states engage themselves in research and innovation thus leading to a positive linkage [34]. This is also referred to as innovation offset which implies that the innovation causes cost reduction in production units. This comparative advantage of cost reduction outweighs the comparative advantage of stringent environmental regulations by developing countries [39].

3.1.4. Environmental Kuznets Curve. This theory develops a nexus between income and environmental pollution (per capita). There has been an extensive research on economic growth and its impact on sustainability. Existing literature can be classified into three distinct groups of researchers [40]. In the beginning, researchers worked to determine the presence of inverted U-shaped relationship among economic growth and carbon emissions [41]. Opponents of the Kuznets hypothesis worked to explain the nexus between economic growth and income inequality. Later on, the Kuznets curve got modified to explain the relationship between economic growth and environmental quality and is referred to as Environmental Kuznets Curve (EKC).

\subsection{Developing Relationship between FDI, GDP, and Energy} Consumption. This study investigates the influence of FDI, GDP, and energy consumption on polluting emissions and its impact on Pakistan. Climate change in statistical 

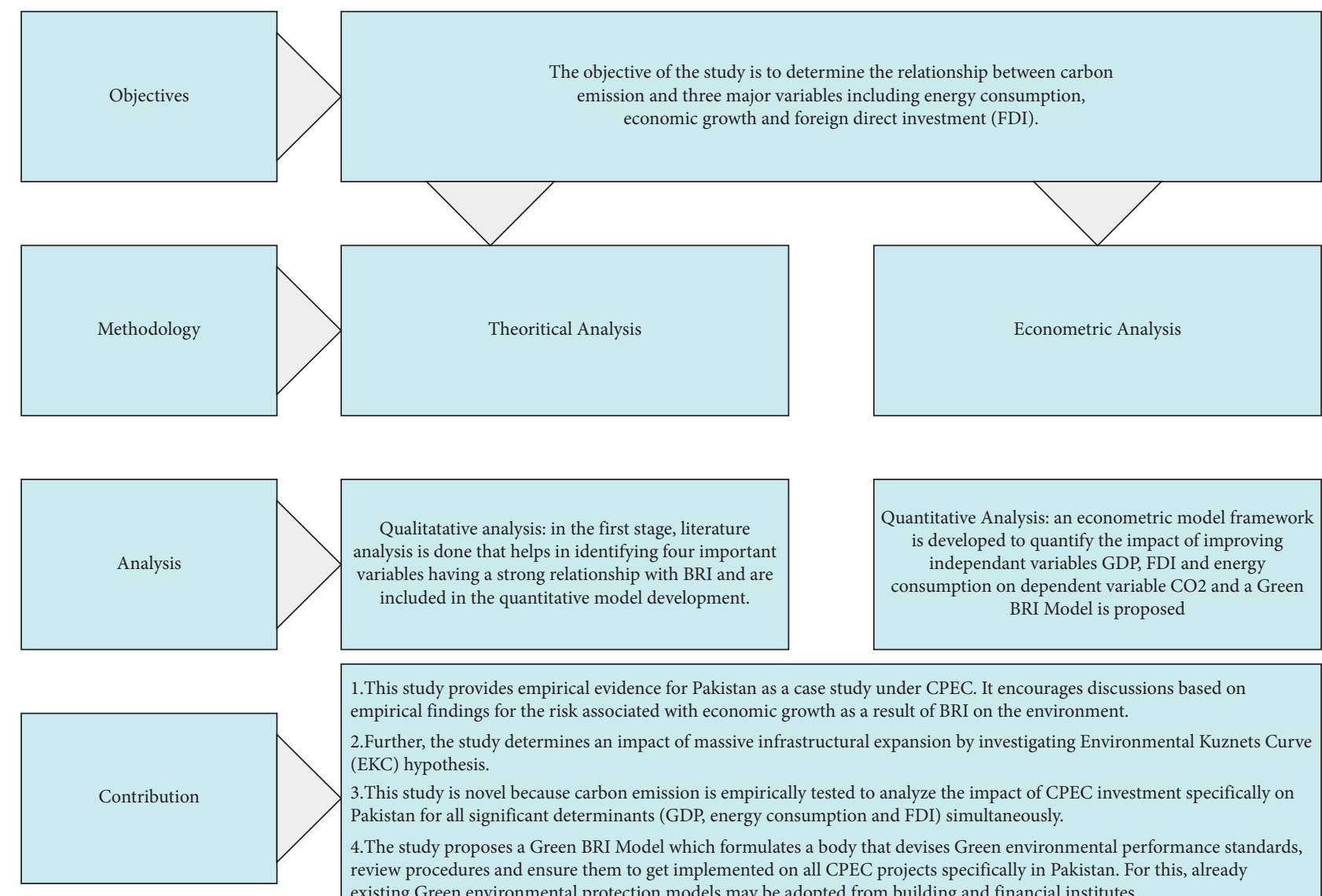

1.This study provides empirical evidence for Pakistan as a case study under CPEC. It encourages discussions based on empirical findings for the risk associated with economic growth as a result of BRI on the environment.

2.Further, the study determines an impact of massive infrastructural expansion by investigating Environmental Kuznets Curve (EKC) hypothesis.

3. This study is novel because carbon emission is empirically tested to analyze the impact of CPEC investment specifically on Pakistan for all significant determinants (GDP, energy consumption and FDI) simultaneously.

4.The study proposes a Green BRI Model which formulates a body that devises Green environmental performance standards, review procedures and ensure them to get implemented on all CPEC projects specifically in Pakistan. For this, already existing Green environmental protection models may be adopted from building and financial institutes.

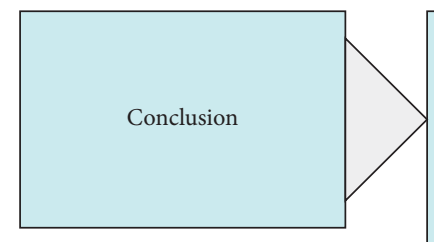

This study infers that "Belt and Road" offers vast benefits for future prosperity of the region but at the same time, it may pose risk of environmental degradation. This study is novel because carbon emission is empirically tested to analyze the impact of CPEC investment for all significant determinants (GDP, energy consumption and FDI) simultaneously. It shows existence of long term casualty between $\mathrm{CO} 2$ and other three variables GDP, FDIn and EnCOur model indicates presence of one cointegrated equations suggesting the presence of a long-term relationship between the $\mathrm{CO} 2$ and independent variables and a short run association running from $\mathrm{EnC}$ to $\mathrm{CO} 2$.

The study proposes a Green BRI Model which formulates a body that devises Green environmental performance standards.

FIGURE 1: Block diagram representing structure of the study.

distribution of weather patterns is one of the most contemplate environmental issues across the globe. Certain human activities have been identified as primary cause of ongoing change in climate. Economic development and globalization are the factors which have contributed tremendously to mounting up the emission of $\mathrm{CO}_{2}$ and other residues of GHG in the atmosphere. Political leaders and climate professionals have been augmenting over the dilemma of climate change. The impact of greenhouse gases on the atmosphere has been elevated to more than $60 \%$ with the consequence of carbon dioxide emissions [42]. Globalization plays significant role in the enlargement of economy on an international level. Technological competence, foreign direct investment (FDI), and access to international global market have prospered world economies since mid-twentieth century. This has resulted in a rapid increase in energy consumption. Energy is necessary to carry out all economic activities. In order to achieve better living standards and to sustain economic advancement, developing countries have been depleting massive amounts of energy. However, owing to huge energy consumption, pollutants are released which lead to climate change [43]. In countries such as India, usage of large amounts of energy and the emission of $\mathrm{Co}_{2}$ are constantly mounting thus grabbing worldwide focus. It is imperative to realize the existence of concrete evidence for interaction of these determinants based on exiting literature. We validate the evidence from following studies.

Initially, some researchers examined nexus among environment pollution and economic growth based on data from urban areas of 42 distinct countries [44]. Their findings reveal that environmental pollution increases initially but gradually declines when economy reaches to the threshold of real GDP per capita. Later, the relationship between energy pollutants and income growth was found to support the EKC hypothesis [45]. But an inverted U-shaped relationship could not be validated between income and energy pollutants [46]. 
Some researchers [47] developed the nexus between emission of carbon and economic growth in Austria. The study determined an inverted U- and N-shaped association among growth and detrimental carbon emissions. An inverted U-shaped nexus is found for OECD states when the relationship between economic growth and emission of dissimilar energy sources is studied [48]. Others analyzed linkage between income and environment quality. For this, they collected data from 94 different countries [49]. Findings reveal existence of $\mathrm{U}$-shaped and inverted $\mathrm{N}$-shaped relationships between the variables. Research was carried out to study relationship in presence of intracountry income inequality that supports EKC hypothesis [50]. They found a positive association between income inequality and its impact on carbon emissions thus supporting evidence for validity of EKC hypothesis.

On the contrary, some of the researchers have rejected existence of positive impact of FDI on a receiver country [51]. Based on this hypothesis, the effect of FDI was empirically studied for economic growth. It was found that economic growth is not influenced by FDI; however, FDI hampers growth of per capita income indicating a positive association.

The impact of FDI is also analyzed in a study for 12 countries by implementing Granger causality test [52]. It observes that FDI inflows do not significantly enhance environmental degradation. Based on Granger causality test, another researcher deduced that there exists a unidirectional causality between the growth of FDI and environmental pollution [53], whereas a study carried out a few years ago in Kenya notices a negative association between trade openness and $\mathrm{CO}_{2}$ emission [54]. Similar findings are also obtained by some other researchers [55].

Another study finds that FDI and trade openness may positively or negatively affect $\mathrm{CO}_{2}$ emissions because its effect is variable; therefore, coefficient of trade can be positive or negative [56]. Furthermore, a positive relation for trade and $\mathrm{CO}_{2}$ emission is observed in some other studies [57]. Similar results are gathered for Japan, Mauritius, and Indonesia. Findings [51] reveal that FDI positively influences $\mathrm{CO}_{2}$ emissions in Indonesia.

3.3. Direction of Parameters. In the light of theories that revolve around FDI, GDP, energy consumption, and carbon emission, we postulate the direction of parameters used in this study as stated in Table 2 .

(i) According to Environmental Kuznets Curve, (a) the direction of economic growth is positive; (b) if quadratic variable is included then its direction is negative

(ii) Increase in energy consumption leads to increase in economic growth and ultimately increases environmental pollution

(iii) The direction of FDI parameter is ambiguous and may be positive and/or negative because of the existence of theories contrary to each other (pollution haven and halo effect hypothesis) [58]
3.4. Comparative Analysis. Initially, due to lack of adequate data, researchers used simple cross sections and panel data in their studies. But with the passage of time, refined data has been easily available giving rise to greater number of studies based on time series analysis. Table 3 shows the recent research based on previous studies comprising of time series data for determining the relationship of carbon emission and its impact.

We further explore the findings of different researchers on BRI and its impact on the region. It helps us to differentiate this study from existing research conducted in the same field. Table 4 shows the result.

After the detailed analysis of various studies, we infer the final variables that are to be used in this paper. Selected variables are represented below in Figure 2.

\subsection{Methodology}

3.5.1. Sample Design. Based on theoretical analysis, we find that carbon dioxide is an important variable resulting from BRI projects. It is also established that BRI investment greatly impacts FDI and GDP (indicating economic growth) of participating countries. Therefore, these both variables (FDI, GDP) are also included in our econometric model. Most of CPEC projects include energy ventures; therefore, energy consumption is taken as our last variable. The next phase of our study implies empirical analysis based on time series data for variables including $\mathrm{CO}_{2}$, FDI, Energy Consumption, and GDP from 1979 to 2019 for Pakistan (for a period of 40 years). We have collected data from World Data Bank, the global economy, Economic Survey of Pakistan (2019) [92], and International Energy agency (IEA).

3.5.2. Model Specification. The model implies $\mathrm{CO}_{2}$ per capita for emissions (in metric tons), economic growth as country's annual GDP per capita, FDI as percentage of GDP, and energy consumption per capita. This section of paper deals with theoretical linkage between EKC hypothesis and four major determinants used in this study.

This hypothesis explains the environmental behavior by suggesting that when income level of a unit improves in an economy, it causes degradation of ecosystem. The expansion of economic activity contributes to more pollution emitted in environment. Interestingly, it is found that, at a certain point of increase in income level and growth, there is a gradual improvement in air quality index. The study further explains that, initially, pollution and dirt are ignored but once the high-income level is attained, efforts are made to improve the condition of environmental deterioration.

We develop a linear quadric function that forms a linkage for $\mathrm{CO}_{2}$ emission, foreign direct investment as FDIn, Energy Consumption as EnC, and economic growth as GDP on the basis of EKC hypothesis. For this, we develop long run association among variables for testing validity of EKC hypothesis as below: The general equation of the model is represented as 
TABLE 2: Parameter expectation.

\begin{tabular}{lcccc}
\hline Explanatory variables & Symbol & Hypothesis & Expected sign \\
\hline $\begin{array}{l}\text { Gross domestic product per } \\
\text { capita }\end{array}$ & GDP & Gross domestic product per capita has a positive relation with $\mathrm{CO}_{2}$ & Positive \\
$\begin{array}{l}\text { Foreign direct investment } \\
\text { Energy consumption }\end{array}$ & FDI & Foreign direct investment has a positive relation with $\mathrm{CO}_{2}$ emission. & $\begin{array}{l}\text { Positive/ } \\
\text { negative }\end{array}$ \\
\hline
\end{tabular}

TABLE 3: EKC study based on $\mathrm{CO}_{2}$ emission using time series data.

\begin{tabular}{|c|c|c|c|c|}
\hline Author's name & Time period & Region & Year & Conclusion \\
\hline Atwi et al. [59] & 2018 & 182 countries & $1992-2011$ & Inverted U-shape \\
\hline Dogan and Turkekul [60] & 2016 & USA & $1960-2010$ & Inc. monotonically \\
\hline Balaguer and cantavella [61] & 2016 & Spain & $1974-2011$ & Inverted U-shape \\
\hline Al-Mulali et al. [62] & 2015 & Vietnam & $1981-2011$ & Inc. monotonically \\
\hline Yavuz [63] & 2014 & Turkey & $1960-2007$ & Inverted U-shape \\
\hline Lau et al. [64] & 2014 & Malaysia & $1970-2008$ & Inverted U-shape \\
\hline Alam [65] & 2014 & Bangladesh & $1972-2010$ & Inc. monotonically \\
\hline Kholer [66] & 2013 & South Africa & 1960-2009 & Inverted U-shape \\
\hline Jayanthakumaran et al. [67] & 2012 & China/India & $1971-2007$ & Inverted U-shape \\
\hline Iwata et al. [10] & 2012 & 11 OECD countries & $1967-2003$ & Inc. monotonically \\
\hline Iwata et al. [68] & 2010 & France & $1900-2003$ & Inverted U-shape \\
\hline He and Richard [69] & 2010 & Canada & $1948-2004$ & Inc. monotonically \\
\hline Akbostanci et al. [70] & 2009 & Turkey & $1968-2003$ & Inc. monotonically \\
\hline Soytas et al. [71] & 2007 & United States & $1960-2004$ & Inc. monotonically \\
\hline Kunnas and Myllyntaus [72] & 2007 & Finland & $1800-2003$ & Inc. monotonically \\
\hline
\end{tabular}

TABLE 4: Research and findings on BRI.

\begin{tabular}{|c|c|c|}
\hline Author(s) & Description & Research title \\
\hline Zaman et al. [73] & $\begin{array}{l}\text { The study aims to determine environmental, social, } \\
\text { technological, and governance (ESTG) effect with } \\
\text { specific characteristics and the newly defined principles } \\
\text { associated with the BRI. It further analyzes the risks }\end{array}$ & $\begin{array}{l}\text { ESTG BRI: principles for a sustainable belt and road } \\
\text { initiative }\end{array}$ \\
\hline
\end{tabular}

This research explores information and communication sector under BRI. It concludes that digital silk road is the key to global multilateralism. It also helps in Ly and Albert [74] financial stability and economic growth. It also involves Challenge and perspective for digital silk road the risks associated with breech of privacy, data theft, and political ideology.

This study infers that the economic growth, FDI, and

Belt and road economics: opportunities and risks of transport corridor trade may only improve if policy reforms are strictly implemented, thus resulting in transparency and sustainable development.

World bank group [75]

Maliszewska and van der
Mensbrugghe [76]

Elkind [77]

This paper analyzes that if infrastructure is improved under BRI and non-BRI countries, it will lead to

positive impact on trade flow, poverty, and growth. It will simultaneously increase $\mathrm{CO}_{2}$ emission. It also emphasizes on improving policy reforms.

The study aims to quantify and minimize BRI impact on climate change. It also proposes ways to mitigate impact by binding environmental policies.

This research uses a gravity model and a comparative advantage model to determine the difference of bilateral time to trade before and after BRI. Later it then compares bilateral export values and trade patterns. The results confirm an increase in trade reforms.
The belt and road initiative economic, poverty, and environmental impacts

Towards a real green belt and road

Trade effects of the new silk road: a gravity analysis 
TABLE 4: Continued.

\begin{tabular}{lcc}
\hline Author(s) & Description & Research title \\
\hline Visvizi et al. [79] & $\begin{array}{c}\text { This paper explores the impacts of BRI on economic } \\
\text { growth, business prosperity, political ideology, and } \\
\text { society. }\end{array}$ & $\begin{array}{c}\text { Belt and road initiative (BRI): new forms of } \\
\text { international and cross-industry collaboration for } \\
\text { sustainable growth and development }\end{array}$ \\
\hline Khan et al. [80] & $\begin{array}{c}\text { The study devises a theoretical framework based on } \\
\text { nonsystematic analysis of 120 statements issued by } \\
\text { Chinese government to analyze sustainable } \\
\text { development of BRI. }\end{array}$ & $\begin{array}{c}\text { China's belt and road initiative: a global model for an } \\
\text { evolving approach to sustainable } \\
\text { regional development }\end{array}$ \\
\hline
\end{tabular}

The research explores alternative means of energy mix to compare with emission based on energy ventures under CPEC.

Reynolds et al. [81] The levelized cost of present CPEC projects is quantified for electricity, $\mathrm{CO}_{2}$ emissions, and $\mathrm{SO}_{2}$. An optimization model LCOE is built which reveals that less polluting options using large regasified liquid natural gas plants and hydroprojects are available.

The research analyzes existing literature based on different regions and finds them inadequate. There exists an absence of research on CPEC based on the pollution haven hypothesis and the halo effect

Zubedi et al. [82] hypothesis. It further proposes policy makers the ways

Sustaining low-carbon emission development: an energy efficient transportation plan for CPEC to mitigate GHG emission and proposes an energy efficient transportation model [83-90].

This paper explores the impact of BRI strategy on OECD countries and recipient countries under BRI. It China's belt and road initiative in the global trade, infers that connectivity infrastructure is the key for BRI that affects trade, financial stability, and investment investment

OECD, business, and finance outlook 2018 [91]

Environmental and economic impacts of the BRI on Pakistan's energy sector

$$
\begin{aligned}
& \text { scope. } \\
\ln C O 2_{t}= & \beta_{0}+\beta_{1} \ln F D I n_{t} \\
& +\beta_{2} \ln F D I n_{t}^{2+} \beta_{3} \ln G D P_{t}+\beta_{4} \ln E n C_{t}+\mu_{t} .
\end{aligned}
$$

In the above equation, log (ln) of all variables is taken. Here $\mathrm{CO}_{2}$ shows per capita emission of carbon, FDIn as net inflows percentage of GDP, GDP as annual economic growth (per capita), and EnC as energy consumption per capita (metric tons), whereas $\mu_{\mathrm{t}}$ is a standard error term as stated in Table 5.

3.5.3. Model Explanation. We have applied Multilinear Regression Model. We examine FDI, GDP, energy consumption, and its impact on carbon emission of Pakistan on time series data. We first determine the long term relationship between the variables. Further, we have used unit root test when the data is not stationary at level. When we choose two or more than two variables to test in our empirical model, the result may show existence of more than one cointegrating vector. In case of multiple equations, Johansen cointegration approach is the most appropriate method for estimating various cointegrating vectors. So, Johansen's cointegration test is applied to determine long run association [93]. We have applied the method of maximum likelihood estimates. It helps in detecting number of cointegrating vectors by maximum eigen value and trace statistics. The first indispensable step is to determine presence of unit roots in variables. The method was introduced by Augmented Dickey-Fuller (ADF) [94] and Philips and Perron [95]. This determines order of variables' integration.

\subsection{Model Techniques}

3.6.1. Unit Root Test. We run this test in order to determine if the variable of time series is nonstationary. A nonstationary variable has a unit root and normally becomes stationary at first difference. According to null hypothesis in our model, there exists a unit root, whereas alternative hypothesis states the presence of stationary, trend stationary, or explosive root based on the analysis method applied for testing. Other tests include Phillips-Perron tests, KPSS test, ADF-GLS tests, and Zivot-Andrews tests developed by Elliott, Rothenberg, and Stock [96]. We have applied Augmented Dickey-Fuller (ADF) which is suitable when the sample size is large as in our study and shown derived in the following regression equation:

$$
\Delta x_{t}=\alpha+\delta_{t}+\beta x_{t-1}+\sum_{i-1}^{k} \gamma \Delta x_{t-1}+\mu_{t} .
$$

In the above equation, $\Delta x_{t}$ represents the first difference of $x$, whereas $\alpha, \delta, \beta$, and $\gamma$ are parameters that are estimates used in selected model while $\mu_{t}$ shows serial correlation errors. For presence of unit root, we present null hypothesis and alternative hypothesis. Variable used is $x_{t}$ : 


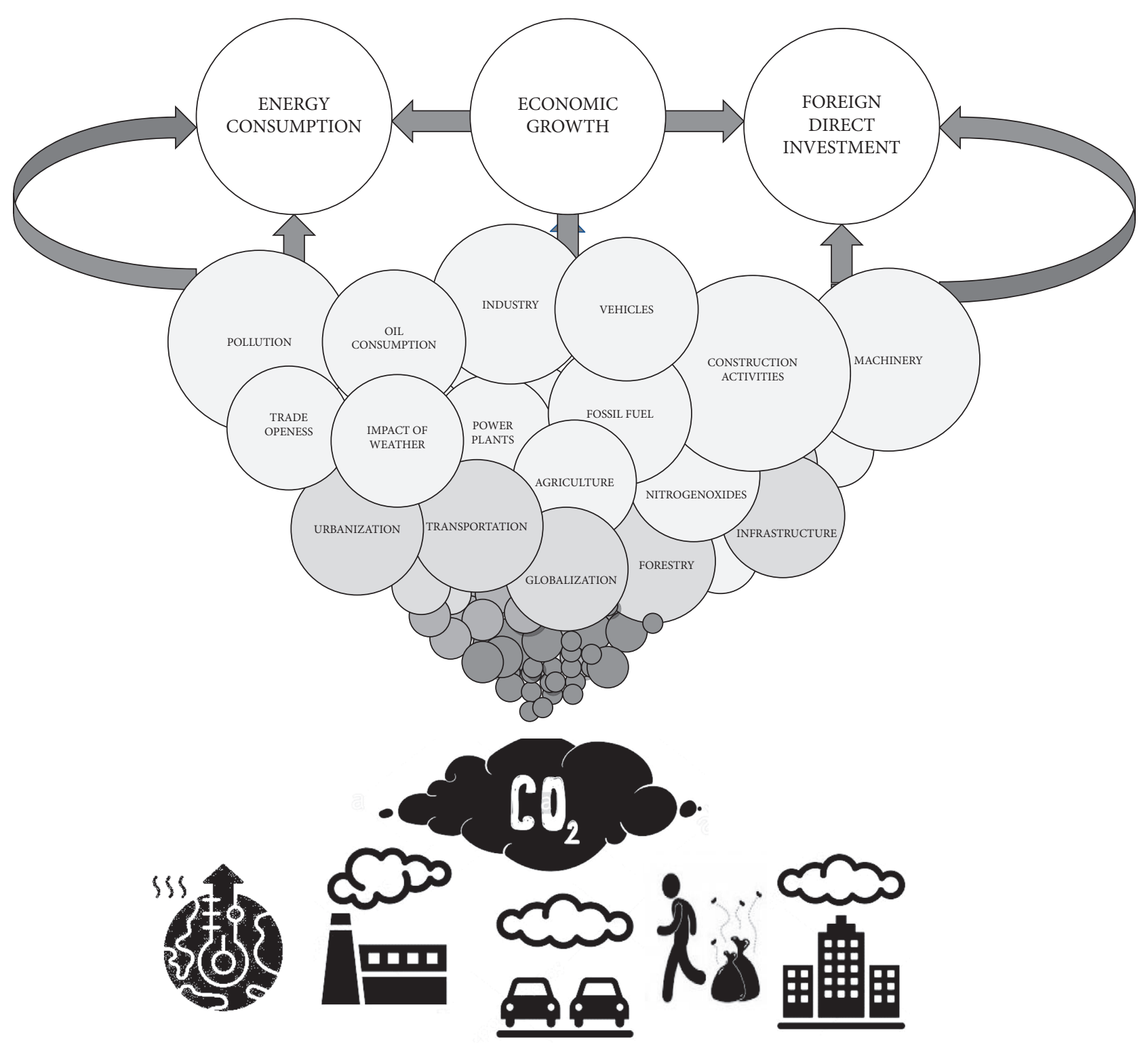

FIGURE 2: Diagram representing selected variables.

TABle 5: Variables explanation.

\begin{tabular}{lc}
\hline Denotation & Variable \\
\hline $\ln \mathrm{CO} 2_{\mathrm{t}}$ & Natural log of $\mathrm{CO}_{2}$ emission per capita \\
$\ln \mathrm{FDIn}$ & Natural log of net inflows percentage of GDP \\
$\ln \mathrm{GDP}$ & $\begin{array}{c}\text { Natural log of annual economic growth (per capita) } \\
\text { Natural log of energy consumption per capita } \\
\text { ln } \mathrm{EnC}_{t}\end{array}$ \\
$\mu_{t}$ & (metric tons) \\
\hline
\end{tabular}

$$
\begin{gathered}
H o=: \beta=1 . \\
H \in=: \beta>0 .
\end{gathered}
$$

First, we need to test null hypothesis in our model. If the test result does not reject null hypothesis, then our data bears unit root for time series and needs to be tackled.
3.6.2. Johansen Cointegration Test. We use this test to develop the cointegrating equation in our model because it uses multiple cointegrating vectors. Another standard approach for testing is Engle and Granger which is a bivariate technique so multivariate analysis is ruled out under the technique of Engle and Granger cointegration test [97]. Conversely, Johansen technique is known as system-based approach for cointegration that lessens the omitted lagged variables bias by taking the lag into the estimation. This method is preferred over Engle Granger method when the sample size is large enough. Johansen's test can be performed by applying trace statistics or with Eigen value.

3.6.3. Trace Test. A number of linear combinations (i.e., I) are analyzed by the trace test to see if they equal a given value (Io). We say that the value of alternative hypothesis is more than given value $(I>I o)$ 


$$
\begin{aligned}
& \text { Ho: } I=I o . \\
& \text { Ho: } I=I o+1 .
\end{aligned}
$$

We check the presence of cointegration applying the trace test. For this, $I o=0$ which shows the absence of cointegration. It should be noted here that we may establish existence of cointegration among variables once we examine and reject null hypothesis. We apply trace test statistics LR (likelihood ratio) for determining order of $r$ as per Johansen's method.

$$
\lambda_{\text {trace }}(q, n)=-T \sum_{i=q+1}^{k} \ln [1-\hat{\lambda} i] .
$$

Here $T$ represents observations count used for estimation, and $\hat{\lambda} i$ is the ith largest estimated Eigen value.

3.6.4. Maximum Eigen Value Test. The analysis criteria for maximum Eigen value test are similar to trace statistics except for the difference in an alternate hypothesis and stated as equations (5) and (6):

$$
\begin{gathered}
\text { Ho: } I=I o . \\
\text { Ho: } I=I o+1 .
\end{gathered}
$$

When we say that $I=I o$, it suggests the possibility of a single combination of the nonstationary variables to yield a stationary process. It is to note that null hypothesis is rejected here. However, this test becomes less reliable as compared to the trace test for the same Io values if we have more than one combination. Johansen proposes the maximum Eigen value test statistics as

$$
\lambda \max (q, q+1)=-T \ln \{1-\lambda-(q+1)\} .
$$

This shows two possibilities. (a) Null hypothesis is rejected for presence of cointegration among the variables $(r=0)$. (b) Cointegration exits between variables $(r \leq 1)$; therefore, null hypothesis is not rejected.

It is imperative to mention again that time series variable needs to be stationary at first difference, i.e., integrated of order one if it is not stationary at level. It is said that if there is a minimum of one linear combination among the variables that are stationary, then the time series variables may be cointegrated. This suggests the existence of a positive long run equilibrium relation between the variables.

3.6.5. Error Correction Model. Error correction model is short and long term approach used on time series data. Scenarios, where underlying variables have a long run stochastic trend called cointegration, may apply an error correction model. The term error correction refers to the last-periods deviation from a long run equilibrium where the term "error" influences its short run dynamics. Thus, ECMs directly estimate the speed at which a dependent variable returns to equilibrium after a change in other variables.

Once the long run estimates are determined, we apply VECM to establish short run estimates. In our chosen system, it is imperative to note that every dependent variable is function of its own lag, error correction term, explanatory variables lags, and the random error term. In this methodology, all variables are taken one by one as endogenous. This means that, in VECM, the number of equation is equal to the number of variables in our chosen system. So, VECM can be modeled as below:

$$
\begin{aligned}
\Delta l C O 2_{t} & =\alpha_{1}+\sum_{i=1}^{P} \beta_{l i} \Delta l C O 2_{t-i}+\sum_{i=1}^{q} \beta_{l i} \Delta l G D P_{t-1}+\sum_{i=1}^{r} \beta_{l i} G D P 2_{t-1}+\sum_{i=1}^{s} \beta_{l i} F D I n_{t-1}+\lambda_{1} E n C_{t-1}+\mu_{1 t}, \\
\Delta l G D P_{t} & =\alpha_{2}+\sum_{i=1}^{P} \beta_{2 i} \Delta l C O 2_{t-i}+\sum_{i=1}^{q} \beta_{2 i} \Delta l G D P_{t-1}+\sum_{i=1}^{r} \beta_{2 i} \Delta G D P_{t-1}^{2}+\sum_{i=1}^{s} \beta_{2 i} \Delta F D I n_{t-i}+\lambda_{2} E n C_{t-1}+\mu_{2 t}, \\
\Delta l G D P 2_{t} & =\alpha_{3}+\sum_{i=1}^{P} \beta_{3 i} \Delta l C O 2_{t-i}+\sum_{i=1}^{q} \beta_{3 i} \Delta l G D P_{t-1}+\sum_{i=1}^{r} \beta_{3 i} \Delta l G D P_{t-1}^{2}+\sum_{i=1}^{s} \beta_{3 i} \Delta F D I n_{t-i}+\lambda_{3} E n C_{t-1}+\mu_{3 t}, \\
\Delta l F D I n_{t} & =\alpha_{4}+\sum_{i=1}^{P} \beta_{4 i} \Delta l C O 2_{t-i}+\sum_{i=1}^{q} \beta_{4 i} \Delta l G D P_{t-1}+\sum_{i=1}^{r} \beta_{4 i} \Delta l G D P_{t-1}^{2}+\sum_{i=1}^{s} \beta_{4 i} \Delta F D I n_{t-i}+\lambda_{4} E n C_{t-1}+\mu_{4 t}, \\
\Delta l E n C_{t} & =\alpha_{5}+\sum_{i=1}^{P} \beta_{5 i} \Delta l C O 2_{t-i}+\sum_{i=1}^{q} \beta_{5 i} \Delta l G D P_{t-1}+\sum_{i=1}^{r} \beta_{5 i} \Delta l G D P_{t-1}^{2}+\sum_{i=1}^{s} \beta_{5 i} \Delta F D I n_{t-i}+\lambda_{5} E n C_{t-1}+\mu_{5 t} .
\end{aligned}
$$

$\mu_{1 t} u_{2 t}, u_{3 t}, u_{4 t}$, and $u_{5 t}$ represent serial uncorrelated error terms in the respective equations, whereas, EnCs represent the cointegrating vectors and $\lambda 1, \lambda 2, \lambda 3, \lambda 4$, and $\lambda 5$ are said to be coefficients of speed of adjustment in the direction of equilibrium.
VECM aids in identifying causality between cointegrated variables. It also assists to determine the differences between short and long run, whereas, EnCs help in measuring the extent to which the error is corrected as a result of random shock for every small to a large period. 


\section{Data Analysis}

This paper uses the descriptive analysis, unit root test, Johansen-Julius cointegration, and vector error correction model techniques. It helps in data analysis and interpretation.

4.1. Regression Analysis and Results. Regression analysis in our model determines the impact of chosen variables on $\mathrm{CO}_{2}$. Results of regression coefficients indicate the positive or negative direction of the variable affecting the dependent variable, i.e., carbon dioxide. Our model analyzes that the predictor variables GDP, FDIn, and EnC positively impact $\mathrm{CO}_{2}$ because the $p$ value is smaller than $5 \%$ significance level in our model whereas the values of $T$-statistic are significant as shown in Table 6. Furthermore, the overall significance of the model is indicated by F-statistic value which is 1291.23. Here, $p$ value is less than significance level and the value of $R 2$ equals 0.9903 . In econometric terminology, it indicates that independent variables are responsible for $99.03 \%$ variation in the dependent variable, i.e., $\mathrm{CO}_{2}$ in our model. If we observe closely, we realize that the value for $R 2$ is significantly high. It may be either because of presence of multicollinearity in our model which is the least desirable or probably because of time series analysis. Therefore, we will further need to test to outweigh the presence of multicollinearity in our model.

4.2. Unit Root Test. We examine our variable for cointegration and need to ensure stationarity of time series data. Therefore, ADF test is applied. The unit root test shows that the variables are integrated of order one I (1) and are stationary at 1 st difference. After fulfilling condition of stationary, we may apply Johansen's test of cointegration on our model.

4.2.1. Unit Root Test for $\mathrm{CO}_{2}$. The series of $\mathrm{CO}_{2}$ data is not stationary at level; therefore, unit root at 1st difference is taken using Dickey-Fuller test for unit root as shown in Table 7. It is evident that the test statistic -6.677 in absolute sense is greater than the critical values $-3.429,-1.686$, and -1.304 at confidence levels $1 \%, 5 \%$, and $10 \%$, respectively. We may suggest that data of $\mathrm{CO}_{2}$ is stationary at 1 st difference as $p$ value $\leq 0.001$ is less than 0.05 rejecting $\mathrm{H} 0$ (the hypothesis of unit root).

4.2.2. Unit Root Test for GDP. Similarly, GDP is not stationary at the level; therefore, it is tested for unit root at first difference. The test statistic values -3.888 in absolute sense are more than the critical values $-2.429,-1.686$, and -1.304 at $1 \%, 5 \%$, and $10 \%$ confidence levels, respectively. We also note that the data is stationary at first difference and there exists no unit root from the $p$ value which is less than 0.05 as shown in Table 8.
4.2.3. Unit Root Test for FDIn. Similar to the results above, FDIn data is not stationary at the level as shown in Table 9. Therefore, ADF test for unit root has been used at the first difference of the data. Here, we observe that the test statistic -4.247 in absolute sense is more than all the critical values $-2.429,-1.686$, and -1.304 at $1 \%, 5 \%$, and $10 \%$, respectively. We have also found in our model that $p$ value is not greater than 0.05. Based on statistical test, we infer that data is stationary at first difference rejecting $\mathrm{HO}$ hypothesis of unit root test.

4.2.4. Unit Root Test for EnC. Again, we have applied ADF test for unit root to convert the EnC data into stationary at first difference because it is not stationary at the level. The test indicates that the test statistic -5.084 in absolute sense is more than the critical values $-2.429,-1.686$, and -1.304 at confidence levels $1 \%, 5 \%$, and $10 \%$, respectively, whereas, $p$ value $\leq 0.001$ is smaller than 0.05 which clearly allows us to reject $\mathrm{H} 0$ (the hypothesis of unit root) and defines that data of EnC becomes stationary at 1st difference as shown in Table 10 .

4.3. Vector Autoregressive Model (VAR) Lag Order Selection. Selection of an optimal lag length of underlying VAR is obligatory in determining dynamic association among variables. This is achieved once stationarity of the variables is tested. We first apply Hannan Quinn, Schwartz information criteria. Further we apply LR and final prediction error to find optimal lag length. Later on, we select optimal lag length of underlying VAR to determine dynamic relationship among variables. If inappropriate lag length is chosen, it misleads the results. Lag order determined on the basis of Akaike information criteria (AIC) leads to reliable and proficient results. Therefore, our study employs AIC and Schwarz Bayesian criteria for selecting lag order. However, minimum value of AIC is evaluated for our decision. In our model, optimal lag length based on VAR lag order selection criterion is 3 as evident in Table 11 .

4.4. Johansen Cointegration Test. Once we ensure that our data is stationary at first difference and optimal lag length is 3 , we may proceed with cointegration test to determine long term relationship between variables. We may check cointegration by Engle Granger Test, autoregressive deterministic test (ARDL), and Johansen's maximum likelihood method. Our model consists of more than one variable so there may be more than one cointegrating vector. Therefore, we choose Johansen's cointegration test because it allows more than one cointegrating relationship unlike Engle Granger method. In cointegration, maximum likelihood ratio test is implemented. This ratio includes trace statistics and max Eigen value statistics. The null hypothesis of cointegration states that, at 0 ranks, there exists no cointegration between the variables. But in our model, we may observe from Table 9 that, at null hypothesis, the values of trace statistics are more than critical values. Therefore, we 
TABLE 6: Regression analysis.

\begin{tabular}{|c|c|c|c|c|c|c|}
\hline \multicolumn{5}{|c|}{ Regress $\mathrm{CO}_{2}$ GDP FDIn EnC } & \multicolumn{2}{|c|}{ Number of obs $=40$} \\
\hline \multicolumn{7}{|c|}{$F(3.38=1291.23)$} \\
\hline Source & SS & $\mathrm{df}$ & & MS & \multicolumn{2}{|c|}{ Prob $>F=0.001$} \\
\hline Model & 1.75595638 & 3 & & 0.585318794 & \multicolumn{2}{|c|}{$R$-squared $=0.9903$} \\
\hline Residual & 0.017225523 & 38 & & 0.000453303 & \multicolumn{2}{|c|}{$\begin{array}{c}\text { Adj } R \text {-squared }=0.9895 \\
\text { Root MSE }=0.2129\end{array}$} \\
\hline Total & 0.7731819 & 41 & & 0.04324833 & \multirow{2}{*}{\multicolumn{2}{|c|}{ [95\% conf. interval] }} \\
\hline $\mathrm{Co} 2$ & Coef. & Std.err & $t$ & $p>[t]$ & & \\
\hline GDP & 0.0002889 & 0.0000583 & 4.95 & 0.000 & 0.0001708 & 0.000407 \\
\hline FDIn & 0.0128604 & 0.0061671 & 2.09 & 0.044 & 0.0003758 & 0.025345 \\
\hline $\mathrm{EnC}$ & 0.0020487 & 0.0001818 & 11.27 & 0.000 & 0.0016806 & 0.0024167 \\
\hline _cons & -0.4192743 & 0.0328253 & -12.77 & 0.000 & -0.4857257 & -0.3528229 \\
\hline
\end{tabular}

TABle 7: Unit root test for $\mathrm{CO}_{2}$.

\begin{tabular}{|c|c|c|c|c|}
\hline Dickey-Fuller test for unit root & \multicolumn{2}{|c|}{ Number of obs $=40$} & \multicolumn{2}{|c|}{$Z(t)$ has t-distribution } \\
\hline$Z(t)$ & $\begin{array}{c}\text { Test } \\
\text { Statistics } \\
-6.677\end{array}$ & $\begin{array}{c}1 \% \text { critical } \\
\text { Value } \\
-3.429\end{array}$ & $\begin{array}{c}5 \% \text { critical } \\
\text { Value } \\
-1.686\end{array}$ & $\begin{array}{c}10 \% \text { critical } \\
\text { Value } \\
-1.304\end{array}$ \\
\hline
\end{tabular}

$p$ value for $Z(t) \leq 0.001$.

TABLE 8: Unit root test for GDP.

\begin{tabular}{|c|c|c|c|c|}
\hline Dickey-Fuller test for unit root & & $=40$ & $Z(t$ & ution \\
\hline$Z(t)$ & $\begin{array}{c}\text { Test } \\
\text { Statistics } \\
-3.888\end{array}$ & $\begin{array}{c}1 \% \text { critical } \\
\text { Value } \\
-2.429\end{array}$ & $\begin{array}{c}5 \% \text { critical } \\
\text { Value } \\
-1.686\end{array}$ & $\begin{array}{c}10 \% \text { critical } \\
\text { Value } \\
-1.304\end{array}$ \\
\hline
\end{tabular}

$p$ value for $Z(t) \leq 0.002$.

TABLE 9: Unit root test for FDIN.

\begin{tabular}{|c|c|c|c|c|}
\hline Dickey-Fuller test for unit root & & $=40$ & $Z(t$ & ution \\
\hline$Z(t)$ & $\begin{array}{c}\text { Test } \\
\text { Statistics } \\
-4.247\end{array}$ & $\begin{array}{c}1 \% \text { critical } \\
\text { Value } \\
-2.429\end{array}$ & $\begin{array}{c}5 \% \text { critical } \\
\text { Value } \\
-1.686\end{array}$ & $\begin{array}{c}10 \% \text { critical } \\
\text { Value } \\
-1.304\end{array}$ \\
\hline
\end{tabular}

$p$ value for $Z(t) \leq 0.001$.

TABle 10: Unit root test for EnC.

\begin{tabular}{|c|c|c|c|c|}
\hline Dickey-Fuller test for unit root & \multicolumn{2}{|c|}{ Number of obs $=40$} & \multicolumn{2}{|c|}{$Z(t)$ has t-distribution } \\
\hline$Z(t)$ & $\begin{array}{c}\text { Test } \\
\text { Statistics } \\
-5.084\end{array}$ & $\begin{array}{c}\% \text { critical } \\
\text { Value } \\
-2.429\end{array}$ & $\begin{array}{c}5 \% \text { critical } \\
\text { Value } \\
-1.686\end{array}$ & $\begin{array}{c}10 \% \text { critical } \\
\text { Value } \\
-1.304\end{array}$ \\
\hline
\end{tabular}

$p$ value for $Z(t) \leq 0.001$.

may deduce that there exists cointegration among variables while rejecting null hypothesis. As we move further, we find that, at rank 1 , the value for trace statistics is 23.6376 which is smaller than $5 \%$ critical value 29.68 . Thus, we may confirm the existence of a long run relationship among the variables in our model. Our findings are further confirmed by max Eigen value. Max statistics 18.9627 is less than 5\% critical value 20.97. The statistic confirms presence of one cointegrating vector among the variables as shown below in Table 12 .
4.4.1. Interpretation. This test is conducted as it provides statistical support for establishing presence of long run association among dependent and independent variables in our model. Values obtained by trace statistic and critical values also indicate presence of long run association. This model indicates that the value of trace statistic on rank 0 is greater than $5 \%$ critical values. Thus, a long run association exists between variables used in our model. Based on the results, we have rejected null hypothesis (i.e., H0= no long run association in the model). 
TABLE 11: VAR lag order selection.

\begin{tabular}{|c|c|c|c|c|c|c|}
\hline \multirow{2}{*}{$\begin{array}{l}\text { Selection-order criteria } \\
\text { LL }\end{array}$} & \multicolumn{3}{|c|}{ Sample: 1979-2019 } & \multicolumn{3}{|c|}{ Number of obs $=40$} \\
\hline & LR & $\mathrm{df}$ & $p$ & FPE & AIC & HQIC \\
\hline $\begin{array}{l}-373.88 \\
19.5465\end{array}$ & & & & 3054.64 & 19.3759 & 19.4371 \\
\hline $\begin{array}{l}-195.907 \\
11.9253^{*}\end{array}$ & 355.84 & 16 & 0.001 & -760587 & 11.0722 & 11.3783 \\
\hline $\begin{array}{l}-171.684 \\
12.1861\end{array}$ & $48.446^{*}$ & 16 & 0.001 & $0.513155^{*}$ & $10.6505^{*}$ & $11.2014^{*}$ \\
\hline $\begin{array}{l}-159.872 \\
13.0833 \\
\text { Endogenous: } \mathrm{CO}_{2} \mathrm{GDP} \\
\text { Exogenous:_cons }\end{array}$ & 23.625 & 16 & 0.098 & 0.683605 & 10.8652 & 11.661 \\
\hline
\end{tabular}

TABLE 12: Results of Johansen cointegration results.

Johansen tests for cointegration

\begin{tabular}{|c|c|c|c|c|c|}
\hline \multicolumn{2}{|c|}{ Trend: constant } & \multicolumn{3}{|c|}{ Number of obs $=40$ Sample: $1979-2019$} & Lags $=2$ \\
\hline & & Prams $L L$ & Eigenvalue & Trace statistics & $5 \%$ critical \\
\hline 0 & & -201.629 & 51.5595 & 47.21 & \\
\hline 1 & 27 & -187.66878 & 0.50244 & $23.6376^{*}$ & 29.68 \\
\hline 2 & 32 & -178.18742 & 0.37754 & 4.6749 & 15.41 \\
\hline 3 & 35 & -175.87045 & 0.10939 & 0.0409 & 3.76 \\
\hline 4 & 36 & -175.84998 & 0.00102 & & \\
\hline \multicolumn{2}{|c|}{ Maximum rank } & Prams $L L$ & Eigenvalue & Max statistics & $5 \%$ critical \\
\hline 0 & 20 & -201.62972 & & 27.9219 & 27.07 \\
\hline 1 & 27 & -187.66878 & 0.50244 & 18.9627 & 20.97 \\
\hline 2 & 32 & -178.18742 & 0.37754 & 4.6339 & 14.07 \\
\hline 3 & 35 & -175.87045 & 0.10939 & 0.0409 & 3.76 \\
\hline 4 & 36 & -175.84998 & 0.00102 & & \\
\hline
\end{tabular}

4.4.2. Result of Johansen Cointegration Test. We check presence of long run relationship for the variables in consideration after establishing optimal lag length. We prefer Johansen test using Johansen maximum likelihood method because of its desirable feature of presence of one or more cointegrating association that lacks in the Engle Granger method. Moreover, Johansen cointegration approach is suitable for resolving multiple equations. It also helps to get estimates for both cointegrating vectors unlike Engle Granger single equation approach. Autoregressive deterministic test (ARDL) is also employed in some studies. In our study, there exist more than two variables. Thus, our model may represent more than one cointegrating vector.

The results of cointegration show that the maximum Eigen value test for the null hypothesis is $r 0=r$ against the alternative hypothesis $r 0>r$, whereas, the trace test shows the null hypothesis of $r 0<r$ against alternative hypothesis $r 0>r$. From trace statistics and the maximum Eigen value, we may confirm the existence of one cointegrating equation. It is also evident from the $p$ values that null hypothesis is rejected which indicates no cointegration as the value is less than 0.05 .

4.5. Vector Error Correction Model (VECM). We further check the disequilibrium factor by running VECM as shown in Table 13. The speed of adjustment towards equilibrium is negative and significant as $p(z)$ is less than $5 \%$. Results also suggest the presence of short run relationship.

4.5.1. Long Term Relationship. In this model, $\mathrm{D}-\mathrm{CO}_{2}$ shows regression equation and lagged values of GDP, FDIn, and EnC as independent variables. The negative and positive indicator of coefficients represent the influence of independent variables (GDP, FDIn, and EnC) on dependent variable. The dependent variable in this model is $\mathrm{CO}_{2}$. Ce1 represents one cointegrating equation. $\mathrm{Ce} 1$ has a value -0.168137 and a significant $p$ value. It shows the existence of long term casualty between $\mathrm{CO}_{2}$ and other three variables GDP, FDIn, and EnC.

4.5.2. Short Term Relationship. To ascertain short term casuality, we see individual lag coefficients and $p$ values for each independent variable (GDP, FDIn, EnC). This helps in determining lagged values of GDP, FDIn, and $\mathrm{EnC}$ for $\mathrm{CO}_{2}$. Table 13 shows that first lag of EnC is significant ( $p$ value is $\leq 0.001$ ) which means only first lag of EnC has a short term casualty with $\mathrm{CO}_{2}$.

Our model indicates presence of one cointegrated equation suggesting the presence of a long term relationship between the $\mathrm{CO}_{2}$ and independent variables and a short run association running from EnC to $\mathrm{CO}_{2}$. 
TABLE 13: Vector error correction model.

\begin{tabular}{|c|c|c|c|c|c|c|c|}
\hline \multicolumn{8}{|c|}{ Vector error correction model } \\
\hline Sample & 1979-2019 & & & & & \multicolumn{2}{|c|}{$\begin{array}{c}\text { No. of observations }=40 \\
\text { AIC }=11.24178\end{array}$} \\
\hline Log likelihood $=-187.6688$ & & & & & & \multicolumn{2}{|c|}{$\mathrm{HQIC}=11.89987$} \\
\hline Det $($ sigma_ml $)=0.1397264$ & & & & & & \multicolumn{2}{|c|}{ SBIC 13.07596} \\
\hline Equation & & Parms & RMSE & $R \_s q$ & $\mathrm{Chi}^{2}$ & \multicolumn{2}{|c|}{$p>\operatorname{chi}^{2}$} \\
\hline D_CO2 & & 10 & 0.024334 & 0.5711 & 38.61395 & \multicolumn{2}{|l|}{0.001} \\
\hline D_GDP & & 10 & 12.4495 & 0.7782 & 101.7654 & \multicolumn{2}{|l|}{0.001} \\
\hline D_FDIn & & 10 & 0.345377 & 0.5670 & 37.97036 & \multicolumn{2}{|l|}{0.001} \\
\hline \multirow[t]{2}{*}{ D_EnC } & & 10 & 8.26289 & 0.4201 & 21.01052 & \multicolumn{2}{|l|}{0.0210} \\
\hline & & Coef. & Std.err. & Z & $p>z$ & 95\% Conf. & Interval \\
\hline \multirow[t]{13}{*}{ D_CO2 } & _ce1 & & & & & & \\
\hline & L1. & -0.0131234 & 0.1011439 & -0.13 & 0.897 & -0.2113618 & 0.1851151 \\
\hline & $\begin{array}{l}\mathrm{CO}_{2} \\
\mathrm{LD}\end{array}$ & -0.6404848 & 0.2393048 & -2.68 & 0.007 & -1.109514 & -0.1714561 \\
\hline & L2D. & 0.2746219 & 0.2618192 & 1.05 & 0.294 & -0.2385344 & 0.7877782 \\
\hline & GDP & & & & & & \\
\hline & LD. & 0000448 & 0.0003654 & -0.12 & 0.902 & -0.0007609 & 0.0006713 \\
\hline & $\begin{array}{l}\text { L2D. } \\
\text { FDIn }\end{array}$ & 0.000183 & 0.000408 & 0.45 & 0.654 & -0.0006167 & 0.0009827 \\
\hline & LD. & 0.0090727 & 0.0119216 & 0.76 & 0.447 & -0.0142933 & 0.0324386 \\
\hline & L2D. & 0.0085962 & 0.0127601 & 0.67 & 0.501 & -0.0164131 & 0.0336055 \\
\hline & EnC & & & & & & \\
\hline & LD. & 0022476 & 0.0007258 & 3.10 & 0.001 & 0.0008249 & 0.0036702 \\
\hline & L2D. & -0.0006161 & 0.0008402 & -0.73 & 0.463 & -0.0022628 & 0.00103061 \\
\hline & _cons & 0.009981 & 0.01322 & 0.75 & 0.450 & -0.0159298 & 0.0358918 \\
\hline
\end{tabular}

\section{Proposal for Green BRI Model Plan and Pakistan}

The idea of Green BRI Guidance was officially in spotlight at the first BRI forum in May 2017 [98]. It was followed by an Ecological and Environmental Cooperation Plan and a statement on Vision and Action in Energy Development in the Belt and Road [99] that ensures safeguarding global environment under BRI policies.

Based on existing climate control policy measures, it is proposed to form a distinct body that devises environmental performance standards, review procedures, and ensures they get implemented on all CPEC projects. Moreover, it is found that there tends to occur more infrastructural development under CPEC so as to increase regional economic growth and trade. But the need of time also emphasizes keeping a watch on regional GHG emission with special reference to Pakistan. So, in the light of above discussion, we further propose to invest in Green BRI infrastructure that will be monitored by a combined action plan of Green BRI guidance, an Ecological and Environmental Cooperation Plan, and a statement on Vision and Action in Energy Development that will specifically be targeting countries under CPEC as shown in Figure 3. The agenda of this plan is to ensure a consensus between countries under CPEC region to coordinate for development of sustainable infrastructure for social, economic, and environmental growth and will agree for mutual assistance and collaboration. It will further be improved by adopting existing environmental protection models from building and financial institutes.

\section{Limitations}

A number of limitations and gaps were found while conducting this research which may be improved for future studies. BRI and CPEC are newly implemented projects, so there is a lack of sufficient data. It is also found that some countries are reluctant in sharing national information openly which is again an obstacle in carrying out empirical analysis on individual country under the region. BRI has also witnessed policy barriers that obstruct smooth continuity of trade and investment projects in countries that already have strict policy implications. Countries that bear weak law and rid situation and poor governance are prone to environmental, social, and corruption risks for indigenous investment projects. China's Belt and Road investment is primarily profit oriented but it fails to establish any concrete guidelines and proper follow-up for safeguard of deteriorating environment. There also exists a big gap in policy reform and its proper implementation for infrastructure and energy ventures that discourages trade and FDI. Development of green infrastructure will help in closing these gaps. There exists an inadequate transparency in proper release and allocation of funds under CPEC projects. 


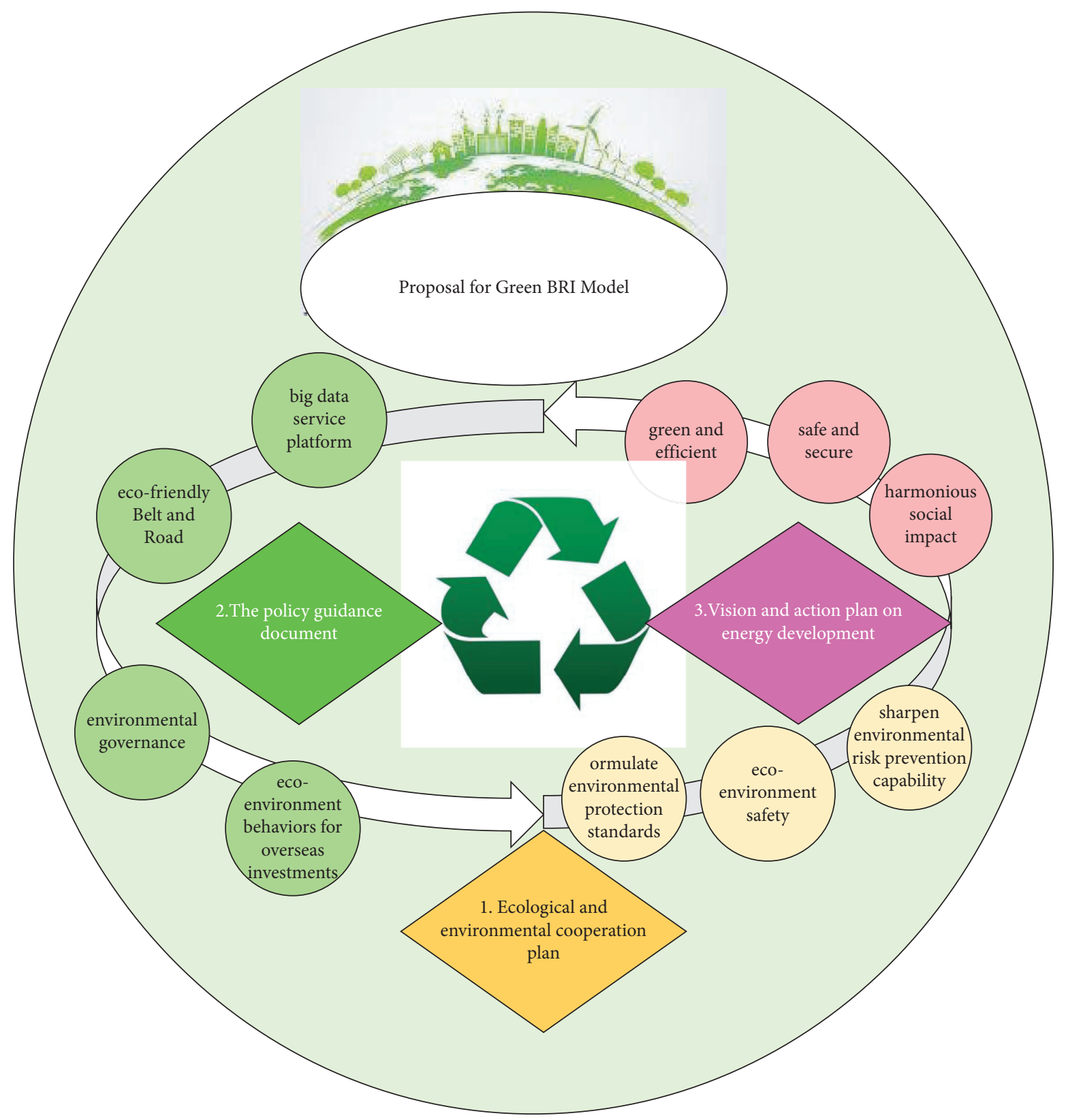

Figure 3: Green BRI Model.

\section{Conclusions}

This paper investigates the Belt and Road Initiative and resulting carbon dioxide emission to find environmental impact of BRI. For the first stage of this analysis, existing literature on BRI is analyzed. It is found that the Belt and Road Initiative has environmental risk factors. FDI under CPEC is aimed primarily for energy ventures in Pakistan and is seen as a perspective for economic growth but, at the same time, it leads to GHG emissions. Based on this, we have selected FDI, $\mathrm{CO}_{2}$, GDP, and energy consumption as our key variables which are analyzed in next stage of this research. The projections made for GHG emissions resulting from average GDP growth in Pakistan (2015-2030) indicate the total increase of $1603 \mathrm{MT}-\mathrm{CO}_{2}$-equivalent in emissions. But the most striking result is that a huge sum of emission (i.e., $370.72 \mathrm{MT}-\mathrm{CO}_{2}$-equivalent) is projected from $\mathrm{CPEC}$ investment alone.

The second stage of this study is based on econometric model to confirm that the results are in consensus and support existing literature. For this, we determine the impact of massive infrastructural expansion by investigating Environmental Kuznets Curve (EKC) hypothesis. For this, we have applied Johansen cointegration tests for a series of data from 1979-2019. Johansen cointegration test statistics confirm the presence of one cointegrating vector among the variables. 
Empirical results in our model indicate presence of one cointegrated equation imlying presence of a long term association between $\mathrm{CO}_{2}$ and independent variables (FDIn, EnC, and GDP). Our $\mathrm{CO}_{2}$ coefficients are consistent with Environmental Kuznets Curve Theory [41]. The long run results imply that the coefficients of energy consumption, economic growth, and foreign direct investments run together. So, we may say that, in Pakistan, energy consumption, economic growth, and FD majorly contribute in carbon emission scenario and have direct relationship with carbon emission as supported by existing literature $[43,50,53]$. It supports the theory that one of the significant sectors is the energy sector that leads to greenhouse gas emissions. The model represents that, in the short run, the coefficient of energy consumption EnC majorly causes carbon emission. Thus, this study does not support the hypothesis of EKC in short run.

The results of short run causality test reveal that a short run association is running from $\mathrm{EnC}$ to $\mathrm{CO}_{2}$. As a matter of fact, the trend of investments made so far indicates more negative impact on local, regional, and global environment. It is further expected to deteriorate the environmental condition if timely measures are not taken.

Until now, too little greening has actually occurred. Nonetheless, the nexus of FDIn and carbon emission in Pakistan is still controversial and needs to be explored further.

This paper offers a novel assessment of the impact of green sustainability under BRI and the current emission scenario in Pakistan. The study also proposes a Green BRI Model which formulates a body that devises environmental performance standards, reviews procedures, and ensures they get implemented on all CPEC projects. Although much discussion on the Belt and Road Initiative is conducted, significant efforts on its effects in the perspective of Pakistan have not been carried so far. In this research, we propose for the first time to form a distinct body that devises environmental performance standards, reviews procedures, and ensures they get implemented on all CPEC projects. Our proposed model for Green BRI (Figure 3) is based on investing in BRI infrastructure that will be monitored by a combined action plan of Green BRI guidance, an Ecological and Environmental Cooperation Plan, and a statement on Vision and Action in Energy Development that will specifically be targeting countries under CPEC. The combination of these approaches will help in building a Green Belt and Road that may be explored further in future research. This research may be useful for policymakers and stakeholders who are interested in investing in energy projects in Pakistan.

\section{Future Perspective}

This study is subject to time series data to quantify the relationship between GHG emission and economic growth specifically in Pakistan under CPEC. This study can be improved by collecting statistical data for more countries on BRI route. Some of the key areas for improvement are mentioned below:
(1) More economic indicators like trade, agriculture, mining, services, manufacturing, and technology can be included to determine their relationship for efficient and reliable results.

(2) The econometric model can be improved by converting first review based phase of study into statistical analysis. For this, carbon dioxide emission resulting from BRI ventures needs to be calculated individually for every country. More data needs to be collected which is currently unavailable/insufficient to support this study.

(3) This study can be improved by including panel and cross section data for entire BRI region.

(4) Under the prospects of BRI, Pakistan attracts foreign direct investment (FDI) from all over the world including China for investment in mega industrial and economic zones.

\section{Data Availability}

It is confirmed that all necessary data are available and may be provided at the request of committee.

\section{Conflicts of Interest}

The authors declare that they have no conflicts of interest.

\section{Authors' Contributions}

Asma Zubedi has contributed in deriving the concept of current study, designing of the research paper, developing the model, analyzing data, and interpreting results and assisted in reaching to final conclusions of this research. Doctor Zeng Jianqiu has supervised this study, guided the formation of paper, and provided laboratory premises to conduct this research. Qasim Ali Arain has contributed in conceptualization and assisted in drafting and final approval for publishing this study. Imran Memon has contributed in providing guidance and leadership for selecting the methodology and assisted in providing mentorship to all authors. Erum Zubedi has contributed in drafting the paper, guided in formatting this study, and assisted in developing the research tools used in this study.

\section{References}

[1] B. Derudder, X. Liu, and C. Kunaka, Connectivity along Overland Corridors of the Belt and Road Initiative, Discussion Paper, MTI Global Practice, Washington: World Bank, October 2018.

[2] J. Wang and M. Westwards, "The rebalancing of China's geostrategy," International and Strategic Studies, vol. 73, 2012.

[3] M. Esteban, The China-Pakistan Corridor: A Transit,economic or Development Corridor? https://www.jstor.org/stable/ 48535947, 2016.

[4] Maplecroft, Global Risks Portfolio and Services, Maplecroft's climate change risk Atlas, 2010, http://www.maplecroft.com/ about/news/climate_change_risk_list_highlights_vulnerable_ nations_\%20and_safe_havens_05.html. 
[5] S. Hamering, Global Climate Risk Index, Germanwatch, Berlin, 2012.

[6] X.-hua Tong, Determinants of Carbon Emission and Primary Energy Consumption Comparative Analysis of China and Japan, pp. 46-51, Contemporary Economy of Japan, Japan, 2008.

[7] National Varieties Study Group of Climate Change in China, Tsinghua University Press, Beijing, 2000.

[8] X.-hua Xu, S. H. I. Hui-xiang, H. Jiang, and D. Wang, "GHG emission and mitigation from energy and transformation industries in Jiangsu-Zhejiang-Shanghai district," Chongqing Environmental Science, vol. 19, pp. 19-21, 1997.

[9] R. Quadrelli and S. Peterson, "The energy-climate challenge: recent trends in $\mathrm{CO} 2$ emissions from fuel combustion," Energy Policy, vol. 35, no. 11, pp. 5938-5952, 2007.

[10] H. Iwata, K. Okada, and S. Samreth, "Empirical study on the determinants of CO2emissions: evidence from OECD countries," Applied Economics, vol. 44, no. 27, pp. 3513-3519, 2012.

[11] S. Kuznet, "Economic growth and income inequality," The American Economic Review, vol. 45, no. 1, pp. 1-28, 1955.

[12] G. H. Grossman and A. B. Krueger, "Economic growth and the environment," Q. J. Public Econ.vol. 57, no. 1, pp. 85-101, 1995.

[13] V. Suri and D. Chapman, "Economic growth, trade and energy: implications for the environmental Kuznets curve," Ecological Economics, vol. 25, no. 2, pp. 195-208, 1998.

[14] S. Dinda and D. Coondoo, "Income and emission: a panel data-based cointegration analysis," Ecological Economics, vol. 57, no. 2, pp. 167-181, 2006.

[15] S. Managi and P. R. Jena, "Environmental productivity and Kuznets curve in India," Ecological Economics, vol. 65, no. 2, pp. 432-440, 2008.

[16] H.-M. Zhu, W.-H. You, and Z.-f. Zeng, "Urbanization and $\mathrm{CO} 2$ emissions: a semi-parametric panel data analysis," Economics Letters, vol. 117, no. 3, pp. 848-850, 2012.

[17] G. M. Grossman and A. B. Krueger, Environmental Impacts of a North American Free Trade Agreement, 2017, http://www. nber.org/papers/w3914.pdf 19913914.

[18] N. Rolland, A Fiber-Optic Silk Road The Diplomat, 2015, http://thediplomat.com/2015/04/a-fiber-optic-silk-road/.

[19] K. C. Das, "The making of one belt, one road and dilemmas in South Asia," China Report, vol. 53, no. 2, pp. 125-142, 2017.

[20] Z. Xudong, China Today, pp. 41-43, February 2015, https:// www.indiatoday.in/world/story/top-chinese-army-general-z hang-xudong-dies-at-58-1862254-2021-10-08.

[21] Z. Kun, International Understanding, pp. 8-12, 2015, https:// www.slideshare.net/GREESHMAPR/international-understan ding\#:\%7E:text=\%EF\%82\%A8\%20International\%20understa nding\%20or\%20internationalism,of\%20local\%20or\% 20national\%20viewpoints.

[22] "Oil and gas climate initiative," 2018, https:// oilandgasclimateinitiative.com.

[23] M. Abrar, "China-Pakistan economic corridor A new vista of development in South Asiall, Pakistan today," 2014, http:// www.pakistantoday.com.pk/2014/12/06/comment/chinapaki stan-economiccorridor-a-new-vista-of-developmentinsouthasia/.

[24] G. Zhuang, Low-Carbon Economy: Under the Context of Climate Change China's Development Road, Meteorological Press, Tharamani, Chennai, Tamil Nadu, 2007.

[25] K. Zhang, J. Pan, and D. Cui, On the Low Carbon Economy, China Environmental Science Press, China, 2008.
[26] N. Stern, The Economics of Climate Change: The Stern Review, Cambridge University Press, Cambridge, UK, 2006.

[27] D. Johnston, R. Lowe, and M. Bell, "An exploration of the technical feasibility of achieving $\mathrm{CO} 2$ emission reductions in excess of $60 \%$ within the UK housing Stock by the year 2050," Energy Policy, vol. 33, pp. 1643-1659, 2005.

[28] Ministry of Climate Change, Pakistan's Intended Nationally Determined Contribution (PAK-INDC) Report, 2016, http:// www4.unfccc.int/ndcregistry/PublishedDocuments/Pakistan\% 20First/Pak-INDC.pdf.

[29] C. Reynolds, T. Stout, X. Wang, and E. Weinthal, Environmental and Economic Impacts of the Belt and Road Initiative on Pakistan's Energy Sector, Nicholas Institute for Environmental Policy Solutions, Durham, North Carolina, 2018.

[30] World Coal Association, The Power of High Efficiency Coal: Reducing Emissions while Delivering Economic Development and Reliable Energy, https://www.worldcoal.org/sites/default/ files/resources_files/The\%20Power\%20of\%20high\%20effici\% 20ency\%20coal\%20-\%20WCA\%20-\%200316.pdf, 2016.

[31] Kelly Sims Gallagher, China's Belt and Road Is Conduit for Polluting Investments, Financial Times, Bracken House, London, England, 2018, https://www.ft.com/content/ f965fa22-9be4-11e8-9702-5946bae86e6d.

[32] Binsar Bakkara, Indonesia Court Allows Dam in Orangutan Habitat to Proceed, The Tribune, Chandigarh, India, 2019.

[33] E. Losos, A. Pfaff, L. Olander, S. Mason, and S. Morgan, "Reducing environmental risks from belt and road initiative investments in transportation infrastructure," Policy Research Working Paper 8718, World Bank, Washington, DC, 2018.

[34] A. Levinson and M. S. Taylor, "Unmasking the pollution haven effect," International Economic Review, vol. 49, no. 1, pp. 223-254, 2008.

[35] M. A. Cole, "Trade, the pollution haven hypothesis and the environmental Kuznets curve: examining the linkages," Ecological Economics, vol. 48, no. 1, pp. 71-81, 2004.

[36] H. Zhu, L. Duan, Y. Guo, and K. Yu, "The effects of FDI, economic growth and energy consumption on carbon emissions in ASEAN-5: evidence from panel quantile regression," Economic Modelling, vol. 58, pp. 237-248, 2016.

[37] C. Zhang and X. Zhou, "Does foreign direct investment lead to lower $\mathrm{CO} 2$ emissions? Evidence from a regional analysis in China," Renewable and Sustainable Energy Reviews, vol. 58, pp. 943-951, 2016.

[38] K. Zeng and J. Eastin, "Do developing countries invest up? The environmental effects of foreign direct investment from less-developed countries," World Development, vol. 40, no. 11, pp. 2221-2233, 2012.

[39] M. E. Porter and C. v. d. Linde, "Toward a new conception of the environment-competitiveness relationship," The Journal of Economic Perspectives, vol. 9, no. 4, pp. 97-118, 1995.

[40] X.-P. Zhang and X.-M. Cheng, "Energy consumption, carbon emissions, and economic growth in China," Ecological Economics, vol. 68, no. 10, pp. 2706-2712, 2009.

[41] S. Kuznets, "Economic growth and income inequality," The American Economic Review, vol. 45, pp. 1-28, 1955.

[42] I. Ozturk and A. Acaravci, "CO2 emissions, energy consumption and economic growth in Turkey," Renewable and Sustainable Energy Reviews, vol. 14, no. 9, pp. 3220-3225, 2010.

[43] K. Alkhathlan and M. Javid, "Energy consumption, carbon emissions and economic growth in Saudi Arabia: an aggregate and disaggregate analysis," Energy Policy, vol. 62, no. C, pp. 1525-1532, 2013. 
[44] G. Grossman and A. Krueger, Environmental Impacts of a North American Free Trade Agreement, National Bureau of Economics Research Working Paper, Cambridge, 3194, 1991.

[45] D. I. Stern, M. S. Common, and E. B. Barbier, "Economic growth and environmental degradation: the environmental Kuznets curve and sustainable development," World Development, vol. 24, no. 7, pp. 1151-1160, 1996.

[46] J. R. Vincent, "Testing for environmental Kuznets curves within a developing country," Environment and Development Economics, vol. 2, no. 4, pp. 417-431, 1997.

[47] B. Friedl and M. Getzner, "Determinants of CO2 emissions in a small open economy," Ecological Economics, vol. 45, no. 1, pp. 133-148, 2003.

[48] S. Galeotti, S. Heal, M. A. Kaminski et al., "The ELMO event in the classical Tethyan setting of the Contessa Road section," in Climate and Biota of the Early Paleogene 2006 Volume of Abstracts, F. Caballero, E. Apellaniz, J. I. Baceta et al., Eds., p. 48, Bilbao, Gubbio, central Italy, 2006.

[49] M. A. Cole, A. J. Rayner, and J. M. Bates, "The environmental Kuznets curve: an empirical analysis," Environment and Development Economics The environmental Kuznets curve: an empirical analysis, Environment and Development Economics, vol. 2, no. 4, pp. 401-416, 1997.

[50] D. Coondoo and S. Dinda, "Carbon dioxide emission and income: a temporal analysis of cross-country distributional patterns," Ecological Economics, vol. 65, no. 2, pp. 375-385, 2008.

[51] D. H. Linh and S. M. Lin, "Dynamic causal relationships among $\mathrm{CO} 2$ emissions, energy consumption, economic growth and FDI in the most populous Asian countries," Advances in Management and Applied Economics, vol. 5, no. 1, pp. 69-88, 2015.

[52] J. D. Danladi and K. Akomolafe, "Foreign direct investment, economic growth, and environmental concern: evidence from Nigeria," Journal of Economics and Behavioral Studies, vol. 5, no. 7, pp. 460-468, 2013.

[53] E. Zerbo, CO2 Emissions, Growth, Energy Consumption and Foreign Trade in Sub-sahara African Countries, 2015, https:// ideas.repec.org/p/hal/wpaper/hal-01110769.html.

[54] F. Halicioglu, "An econometric study of CO2 emissions, energy consumption, income and foreign trade in Turkey," in Proceedings of the 31st IAEE Annual International Conference Istanbul-Turkey, 11457, Istanbul, Turkey, June 2008.

[55] C. S. Akin, "The impact of foreign trade, energy consumption and income on $\mathrm{CO} 2$ emissions," International Journal of Energy Economics and Policy, vol. 4, p. 3, 2014.

[56] S. Hossain, "An econometric analysis for $\mathrm{CO} 2$ emissions, energy consumption," Economic Growth, Foreign Trade and Urbanization of Japan, Low Carbon Economy, vol. 3, no. 3A, pp. 92-105, 2012.

[57] S. Boopen and N. Harris, "Energy use, emissions, economic growth and trade: evidence from Mauritius," in Proceedings of the 2nd International Conference on International Trade and Investment, Barcelona, Spain, June 2012.

[58] J. Baek and Y. Choi, "Does foreign direct investment harm the environment in developing countries? Dynamic panel analysis of Latin American countries," Economies, vol. 5, no. 4, p. 39, 2017.

[59] M. Atwi, R. Barberán, J. Mur, and A. Angulo, "CO2 Kuznets curve revisited: from cross-sections to panel data models InvestigacionesRegionales," Journal of Regional Research, vol. 40, pp. 169-196, 2018.

[60] E. Dogan and B. Turkekul, "CO2 emissions, real output, energy consumption, trade, urbanization and financial development: testing the EKC hypothesis for the USA," Environmental Science and Pollution Research, vol. 23, no. 2, pp. 1203-1213, 2016.

[61] J. Balaguer and M. Cantavella, "Estimating the environmental Kuznets curve for Spain by considering fuel oil prices (18742011)," Ecological Indicators, vol. 60, pp. 853-859, 2016.

[62] U. Al-mulali, C. F. Tang, and I. Ozturk, "Estimating the environment Kuznets curve hypothesis: evidence from Latin America and the caribbean countries," Renewable and Sustainable Energy Reviews, vol. 50, pp. 918-924, 2015, https:// www.sciencedirect.com/science/article/pii/S13640321150047 $5 \mathrm{X}$.

[63] N. Ç. Yavuz, "CO2Emission, energy consumption, and economic growth for Turkey: evidence from a cointegration test with a structural break," Energy Sources, Part B: Economics, Planning and Policy, vol. 9, no. 3, pp. 229-235, 2014.

[64] L.-S. Lau, C.-K. Choong, and Y.-K. Eng, "Investigation of the environmental Kuznets curve for carbon emissions in Malaysia: do foreign direct investment and trade matter?" Energy Policy, vol. 68, pp. 490-497, 2014.

[65] J. Alam, "On the relationship between economic growth and CO2 emissions: the Bangladesh experience," IOSR Journal of Economics and Finance, vol. 5, no. 6, pp. 36-41, 2014.

[66] M. Kohler, "CO2 emissions, energy consumption, income and foreign trade: a South African perspective," Energy Policy, vol. 63, pp. 1042-1050, 2013.

[67] K. Jayanthakumaran, R. Verma, and Y. Liu, "CO2 emissions, energy consumption, trade and income: a comparative analysis of China and India," Energy Policy, vol. 42, pp. 450-460, 2012.

[68] H. Iwata, K. Okada, and S. Samreth, "Empirical study on the environmental Kuznets curve for $\mathrm{CO} 2$ in France: the role of nuclear energy," Energy Policy, vol. 38, no. 8, pp. 4057-4063, 2010.

[69] J. He and P. Richard, "Environmental Kuznets curve for CO2 in Canada," Ecological Economics, vol. 69, no. 5, pp. 1083-1093, 2010.

[70] E. Akbostanc1, S. Turut-Asık, and G. I. Tunc, “The relationship between income and environment in Turkey: is there an environmental Kuznets curve?" Energy Policy, vol. 37, pp. 861-867, 2009.

[71] U. Soytas, R. Sari, and B. T. Ewing, "Energy consumption, income, and carbon emissions in the United States," Ecological Economics, vol. 62, no. 3-4, pp. 482-489, 2007.

[72] J. Kunnas and T. Myllyntaus, "The environmental Kuznets curve hypothesis and air pollution in Finland," Scandinavian Economic History Review, vol. 55, no. 2, pp. 101-127, 2007.

[73] G. Zaman, L. Monica, and Oehler-Şincai, ESTG BRI: Principles for a Sustainable Belt and Road Initiative. China-CEE Institute Working Paper 9, pp. 1-16, China-CEE Institute, Hungary, 2020.

[74] B. Ly and W. K. T. Albert, "Challenge and perspective for digital Silk road," Cogent Business \& Management, vol. 7, no. 1, p. 1804180, 2020.

[75] Oecd, OECD Business and Finance Outlook 2018, OECD Publishing, Paris, 2019.

[76] M. Maliszewska and D. van der Mensbrugghe, "The belt and road initiative: economic, poverty and environmental impacts," The Belt and Road Initiative: Economic Poverty and Environmental Impacts, World Bank Group, Washington, D.C., United States, 2019.

[77] J. Elkind, "US clean energy transition and implications for geopolitics," in The Geopolitics of the Global Energy Transition 
Lecture Notes in Energy, M. Hafner and S. Tagliapietra, Eds., vol. 73, pp. 47-74, Springer, Cham, 2020.

[78] S. Baniya, N. Rocha, and M. Ruta, Trade Effects of the New Silk Road : A Gravity Analysis, World Bank, Washington, DC, Policy Research Working Paper;No. 8694, https:// openknowledge.worldbank.org/handle/10986/31138\% 20License:\%20CC\%20BY\%203.0\%20IGO, 2019.

[79] A. Visvizi, M. D. Lytras, and P. Jin, "Belt and road initiative (BRI): new forms of international and cross-industry collaboration for sustainable growth and development," Sustainability, vol. 12, p. 193, 2020.

[80] M. Khan, I. Sandano, C. Pratt, and T. Farid, "China's belt and road initiative: a global model for an evolving approach to sustainable regional development," Sustainability, vol. 10, no. 11, p. $4234,2018$.

[81] C. Reynolds, T. Stout, X. Wang, and E. Weintha: 2018, https:// dukespace.lib.duke.edu/dspace/.

[82] A. Zubedi, Z. Jianqiu, Q. A. Arain, and I. Memon, "Sustaining low-carbon emission development: an energy efficient transportation plan for CPEC," Journal of Information, vol. 14, no. 2, 2018.

[83] I. Memon, L. Chen, Q. A. Arain, H. Memon, and G. Chen, "Pseudonym changing strategy with multiple mix zones for trajectory privacy protection in road networks," International Journal of Communication Systems, vol. 31, no. 1, p. e3437, Article ID e3437, 2018.

[84] I. Memon, Q. Ali, A. Zubedi, and F. A. Mangi, "DPMM: dynamic pseudonym-based multiple mix-zones generation for mobile traveler," Multimedia Tools and Applications, vol. 76, no. 22, pp. 24359-24388, 2017.

[85] Q. A. Arain, I. Memon, Z. Deng, M. H. Memon, F. A. Mangi, and A. Zubedi, "Location monitoring approach: multiple mixzones with location privacy protection based on traffic flow over road networks," Multimedia Tools and Applications, vol. 77, no. 5, pp. 5563-5607, 2018, https://doi.org/10.1007/ s11042-017-4469-4.

[86] Q. A. Arain, Z. Deng, I. Memon et al., "Privacy protection with dynamic pseudonym-based multiple mix-zones over road networks," China Communications, vol. 14, no. 4, pp. 89-100, April 2017.

[87] Q. A. Arain, D. Zhongliang, I. Memon et al., "Privacy preserving dynamic pseudonym-based multiple mix-zones authentication protocol over road networks," Wireless Personal Communications, vol. 95, no. 2, pp. 505-521, 2017.

[88] Q. A. Arain, M. A. Uqaili, Z. Deng et al., "Clustering based energy efficient and communication protocol for multiple mix-zones over road networks," Wireless Personal Communications, vol. 95, no. 2, pp. 411-428, 2017.

[89] I. Memon, H. Memon, Q. A. Arain, and Q. A. Arain, "Pseudonym changing strategy with mix zones based authentication protocol for location privacy in road networks," Wireless Personal Communications, vol. 116, no. 4, pp. 3309-3329, 2021.

[90] I. Memon, Q. A. Arain, H. Memon, and F. A. Mangi, "Efficient user based authentication protocol for location based services discovery over road networks," Wireless Personal Communications, vol. 95, no. 4, pp. 3713-3732, 2017.

[91] Oecd, OECD Business and Finance Outlook 2018, OECD Publishing, Paris, 2018.

[92] Economic Survey of Pakistan 2018-19, Government of Pakistan, Pakistan, 2018, http://finance.gov.pk/survey/chapters_ 16/Overview_of_the_Economy.pdf.

[93] S. Johansen and K. Juselius, "Maximum likelihood estimation and inference on cointegration with applications to demand for money," Oxford Bulletin of Economics \& Statistics, vol. 52, pp. 169-210, 1990.

[94] D. A. Dickey and W. A. Fuller, "Distribution of the estimators for autoregressive time series with a unit root," Journal of the American Statistical Association, vol. 74, no. 366a, pp. 427431, 1979.

[95] P. C. B. Phillips and P. Perron, "Testing for a unit root in time series regression," Biometrika, vol. 75, no. 2, pp. 335-346, 1988.

[96] G. Elliott, T. J. Rothenberg, and J. H. Stock, "Efficient tests for an autoregressive unit root," Econometrica, vol. 64, no. 4, pp. 813-836, 1996.

[97] Guidance on Promoting Green Belt and Road, Belt and Road Portal, Hong Kong, 2017, https://eng.yidaiyilu.gov.cn/zchj/ qwfb/12479.htm.

[98] The Belt and Road Ecological and Environmental Cooperation Plan, Belt and Road Portal, Hong Kong, 2017, https://eng. yidaiyilu.gov.cn/zchj/qwfb/13392.\%20htm.

[99] Vision and Actions on Energy Cooperation in Jointly Building the Silk Road Economic Belt and 21st-Century Maritime Silk Road, Belt and Road Portal, Hong Kong, 2017. 